\title{
Effect of Distinct Biocontrol Agents on Okra (Abelmoschus esculentus Monech) for the Selection of Putative Strain
}

\author{
Sony Grace ${ }^{1}$, Mohammad Salman ${ }^{1 *}$ and Deepti Prabha \\ ${ }^{1}$ Department of Seed Science and Technology, H.N.B. Garhwal University, India
}

\begin{tabular}{|l|}
\hline Ke y w o r d s \\
Biocontrol agents, \\
okra, PGPR, \\
$\begin{array}{l}\text { Sustainable } \\
\text { agriculture }\end{array}$ \\
\hline Article Info \\
\hline $\begin{array}{l}\text { Accepted: } \\
\text { 10 January } 2019 \\
\text { Available Online: } \\
\text { 10 February } 2019\end{array}$ \\
\hline
\end{tabular}

A B S T R A C T

Use of biocontrol agent to increase the growth of crop has been an alternative source to meet the demand of growing population. Plant growth promoting rhizobacteria (PGPR) are the soil bacteria inhabiting around/on the root surface and are directly or indirectly involved in promoting plant growth and development via production and secretion of various regulatory chemicals in the locality of rhizosphere. These bacteria competitively colonize the roots of plants and can act as biofertilizers and/or antagonist (biopesticides) or simultaneously both. These characteristics have highlighted the use of efficient microorganisms to improve plant growth and manage soil and plant health with the aim to achieve sustainability in agriculture, which amalgamates environmental health, economic feasibility and social equity ensuring long-term productivity of natural resources and improved livelihood. An experiment was conducted to study the effect of biocontrol agents on okra for the selection of putative strain at the Department of Seed Science \& Technology, Chauras campus, H.N.B Garhwal University, Srinagar (Garhwal), Uttrakhand, India. Selection of putative strain among five bio control agents i.e., Bacillus 218 and Pseudomonas Y-19., FP-37., FP-11., S-90., were examined. Results revealed that there was significant effect of all inoculants on growth of okra. Best results were observed in seeds treated with bio agents Bacillus 218, Pseudomonas FP37 and S-90. This study indicates that PGPR enhance plant growth without use of any chemicals.

\section{Introduction}

Okra (Abelmoschus esculentus Monech) known as Bhindi or lady's finger or gumboo, okra belongs to the family malvaceae having chromosome no. $2 n=130$. There are 38 species under the genus Abelmoschus and is a warm season vegetable grown in the tropical and subtropical countries of the world. The origin of okra is somewhere in African continent. It is one of the most popular because of its easy cultivation quick growing habit short duration dependable yield and its adaptability to various conditions for its tender green pods used as vegetables though sometimes canned and dehydrated.

The edible part of Okra is capsule, dehiscent, elongated, straight or curved which is up to 10-30 centimeters long per 1-4 centimeters wide, green yellow or green sometimes purple or white. It is used as an ingredient in soups, stews and various creole dishes. The dried seeds roasted and ground are used as coffee 
additive or substitute. Okra leaves, buds, flowers, can be eaten cooked, boiled, steamed and curryes. Seeds contain up to $22 \%$ edible oil, so they can be used for extracting oil. Greenish-yellow edible okra has pleasant taste and it is high in unsaturated fats such as linoleic acid. Okra is also well known for its medicinal properties.

Common Okra growing problems are seeds do not germinate if soil is not warm enough with temperature at least $70^{\circ} \mathrm{F}$. Too cool and dry temperature lead to drop of flowers and bud before pods set. Pollination will be poor if temperature rise above $90^{\circ} \mathrm{F}$ or drop below $55^{\circ} \mathrm{F}$. Plants stunted leaves yellow and curl and become deformed due to fungal disease that favors warm soil prevalent in humid region. According to Indian Horticulture Database-2011 there is a slight increase in area and production from 2006-07 to 2010-11. The area has increased from 396.0 thousand ha to 498.0 thousand ha and the production has increased from 4070.0 thousand tons to 5784.0 thousand tons.

These effects can be reduced to some extent by using biological control agent. Plant growth promoting rhizobacteria facilitate the plant growth directly by either assisting in resource acquisition (nitrogen, phosphorus and essential minerals) or modulating plant hormone levels, or directly by decreasing the inhibitory effects of various pathogens on plant growth and development in the forms of bio control agents. Various studies have documented the increased health and productivity of different plant species by the application of plant growth promoting rhizobacteria under both normal and stressed conditions (Ahemad and Kibret 2014).

These characteristics have highlighted the use of efficient microorganisms to improve plant growth and manage soil and plant health with the aim to achieve sustainability in agriculture, which amalgamates environmental health, economic feasibility and social equity ensuring long-term productivity of natural resources and improved livelihood.

Pseudomonas and Bacillus are the well known for their plant growth promotional activity. These soil borne bacteria are emerging as an important tool because of their catabolic activity, root colonizing ability, Capacity to produce a wide range of enzyme and metabolites that help the plant to withstand under various biotic and abiotic conditions.

\section{Materials and Methods}

Okra (Abelmoschus esculentus Monech) known as Bhindi or lady's finger or gumboo, okra belongs to the family malvaceae having chromosome no. $2 \mathrm{n}=130$. There are 38 species under the genus Abelmoschus and is a warm season vegetable grown in the tropical and subtropical countries of the world. The origin of okra is somewhere in African continent. It is one of the most popular because of its easy cultivation quick growing habit short duration dependable yield and its adaptability to various conditions for its tender green pods used as vegetables though sometimes canned and dehydrated.

The edible part of Okra is capsule, dehiscent, elongated, straight or curved which is up to 10-30 centimeters long per 1-4 centimeters wide, green yellow or green sometimes purple or white. It is used as an ingredient in soups, stews and various creole dishes. The dried seeds roasted and ground are used as coffee additive or substitute. Okra leaves, buds, flowers, can be eaten cooked, boiled, steamed and curryes. Seeds contain up to $22 \%$ edible oil, so they can be used for extracting oil. Greenish-yellow edible okra has pleasant taste and it is high in unsaturated fats such as 
linoleic acid. Okra is also well known for its medicinal properties.

Common Okra growing problems are seeds do not germinate if soil is not warm enough with temperature at least $70^{\circ} \mathrm{F}$. Too cool and dry temperature lead to drop of flowers and bud before pods set. Pollination will be poor if temperature rise above $90^{\circ} \mathrm{F}$ or drop below $55^{\circ} \mathrm{F}$. Plants stunted leaves yellow and curl and become deformed due to fungal disease that favors warm soil prevalent in humid region. According to Indian Horticulture Database-2011 there is a slight increase in area and production from 2006-07 to 2010-11. The area has increased from 396.0 thousand ha to 498.0 thousand ha and the production has increased from 4070.0 thousand tons to 5784.0 thousand tons.

These effects can be reduced to some extent by using biological control agent. Plant growth promoting rhizobacteria facilitate the plant growth directly by either assisting in resource acquisition (nitrogen, phosphorus and essential minerals) or modulating plant hormone levels, or directly by decreasing the inhibitory effects of various pathogens on plant growth and development in the forms of bio control agents. Various studies have documented the increased health and productivity of different plant species by the application of plant growth promoting rhizobacteria under both normal and stressed conditions (Ahemad and Kibret 2014).

These characteristics have highlighted the use of efficient microorganisms to improve plant growth and manage soil and plant health with the aim to achieve sustainability in agriculture, which amalgamates environmental health, economic feasibility and social equity ensuring long-term productivity of natural resources and improved livelihood.
Pseudomonas and Bacillus are the well known for their plant growth promotional activity. These soil borne bacteria are emerging as an important tool because of their catabolic activity, root colonizing ability, Capacity to produce a wide range of enzyme and metabolites that help the plant to withstand under various biotic and abiotic conditions.

\section{Results and Discussion}

In the presented study we found that Bioagents Pseudomonas and its strains and Bacillus increases the growth of okra. To increase the growth of okra seeds we used different seed treatments of bioagents (Pseudomonas, Bacillus) at $12 \mathrm{gm} / \mathrm{Kg}$. Effects of different bioagents are shown below (Figure 1).

The following results were observed for different parameters of okra seeds:

\section{Speed of germination}

Highest speed of germination was recorded in T1 (6.55) followed by T5 (5.57) Lowest speed of germination was recorded in T4 (3.66).

\section{Germination percentage}

Highest germination percentage was recorded in T1and T4 (66) and Lowest germination percentage was recorded in T2 and T3 (50).

\section{Root length}

Highest root length was recorded in T5(2.88) followed by T4 (2.28) and Lowest root length was recorded in T2 (1.37) (Table 1).

\section{Shoot length}

Highest shoot length was recorded in T5 (3.70) followed by $\mathrm{T} 1$ (3.53) and Lowest shoot length was recorded in T2 (2.56). 
Table.1 Standardization of different strain according to their effect on morphological growth of okra. Finally three strains Bacillus-218, Pseudomonas strain FP37 and S90 selected on the basis of their performance

\begin{tabular}{|l|l|l|l|l|l|l|}
\hline Treatment & $\begin{array}{l}\text { Speed of } \\
\text { germination }\end{array}$ & $\begin{array}{l}\text { Germination } \\
\text { \% }\end{array}$ & $\begin{array}{l}\text { Root } \\
\text { length } \\
\text { (cm) }\end{array}$ & $\begin{array}{l}\text { Shoot } \\
\text { length } \\
\text { (cm) }\end{array}$ & $\begin{array}{l}\text { Seedling } \\
\text { length } \\
\text { (cm) }\end{array}$ & $\begin{array}{l}\text { Seedling } \\
\text { vigour } \\
\text { index 1 }\end{array}$ \\
\hline T1 & $6.55^{* *}$ & $66.00^{* *}$ & $1.93^{* *}$ & $3.53^{* *}$ & $5.43^{* *}$ & $362.32^{* *}$ \\
\hline T2 & $5.34^{* *}$ & $50.00^{* *}$ & $1.37^{* *}$ & $2.56^{* *}$ & $5.53^{* *}$ & $291.60^{* *}$ \\
\hline T3 & $5.03^{* *}$ & $50.00^{* *}$ & $1.97^{* *}$ & $2.72^{* *}$ & $3.88^{* *}$ & $197.24^{* *}$ \\
\hline T4 & $3.66^{* *}$ & $66.00^{* *}$ & $2.28^{* *}$ & $3.21^{* *}$ & $5.49^{* *}$ & $361.40^{* *}$ \\
\hline T5 & $5.57^{* *}$ & $64.00^{* *}$ & $2.88^{* *}$ & $3.70^{* *}$ & $6.72^{* *}$ & $430.08^{* *}$ \\
\hline CD at 1\% & $1.73^{* *}$ & $13.61^{* *}$ & $0.39^{* *}$ & $2.29^{* *}$ & $3.20^{* *}$ & $239.54^{* *}$ \\
\hline CD at 5\% & $1.19^{*}$ & $9.37^{*}$ & $0.27^{*}$ & $1.58^{*}$ & $2.20^{*}$ & $164.85^{*}$ \\
\hline
\end{tabular}

Fig.1 Effects of different bioagents on growth of okra seedlings *Bioagents with their performance on Towel paper are Bacillus-218 (T1), Pseudomonas- Y19 (T2), Pseudomonas-FP37 (T3), Pseudomonas-FP11 (T4) and Pseudomonas-S90 (T5) respectively

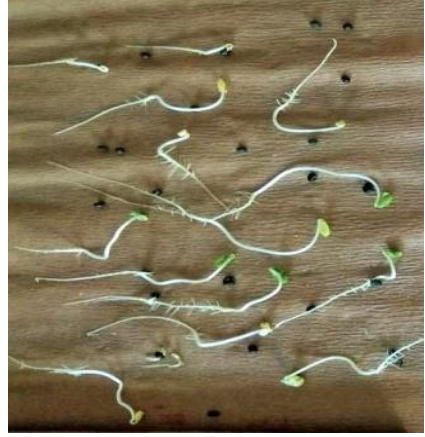

T1

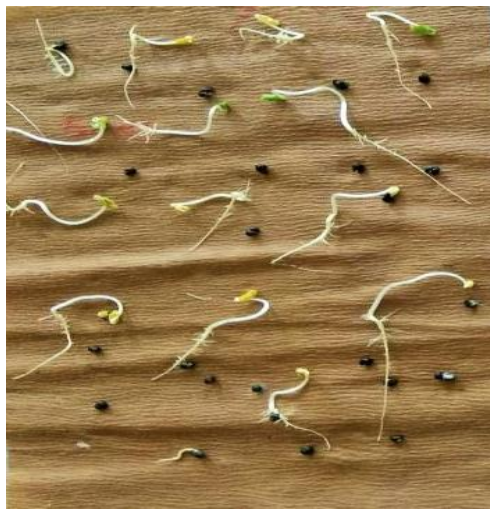

T4

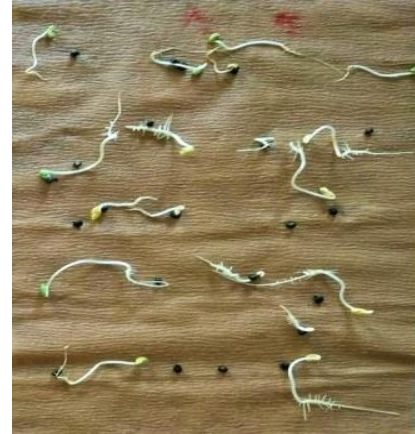

T2

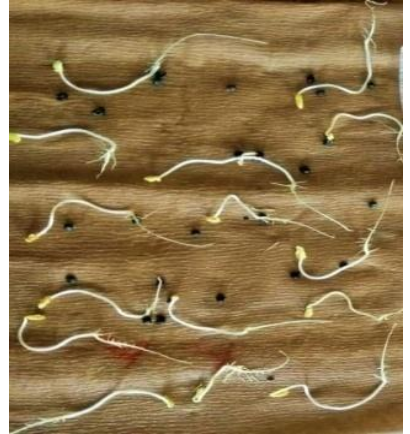

T3 
Figure.2 Figurative representation of different parameters of the five bioagents

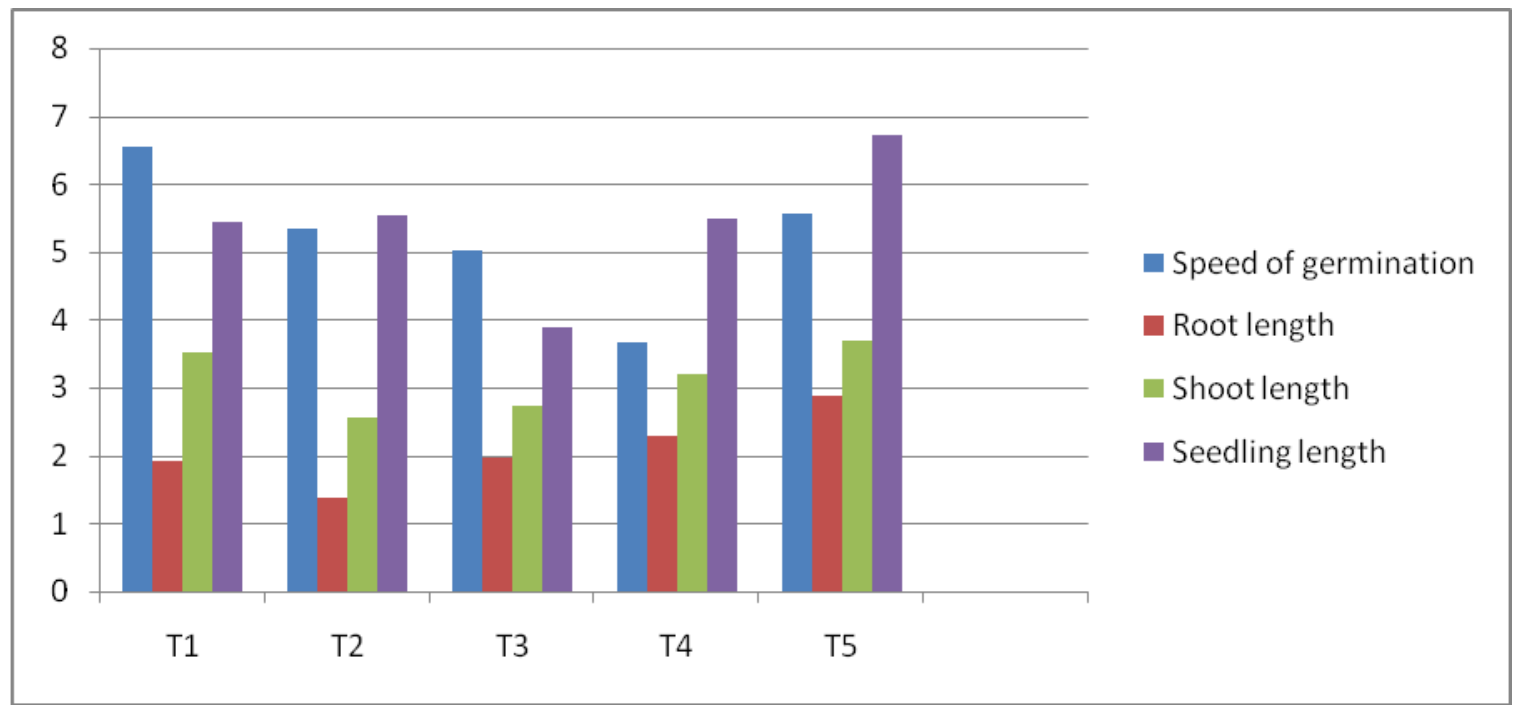

Figure.3 Germination percent and vigour index of the five bioagents

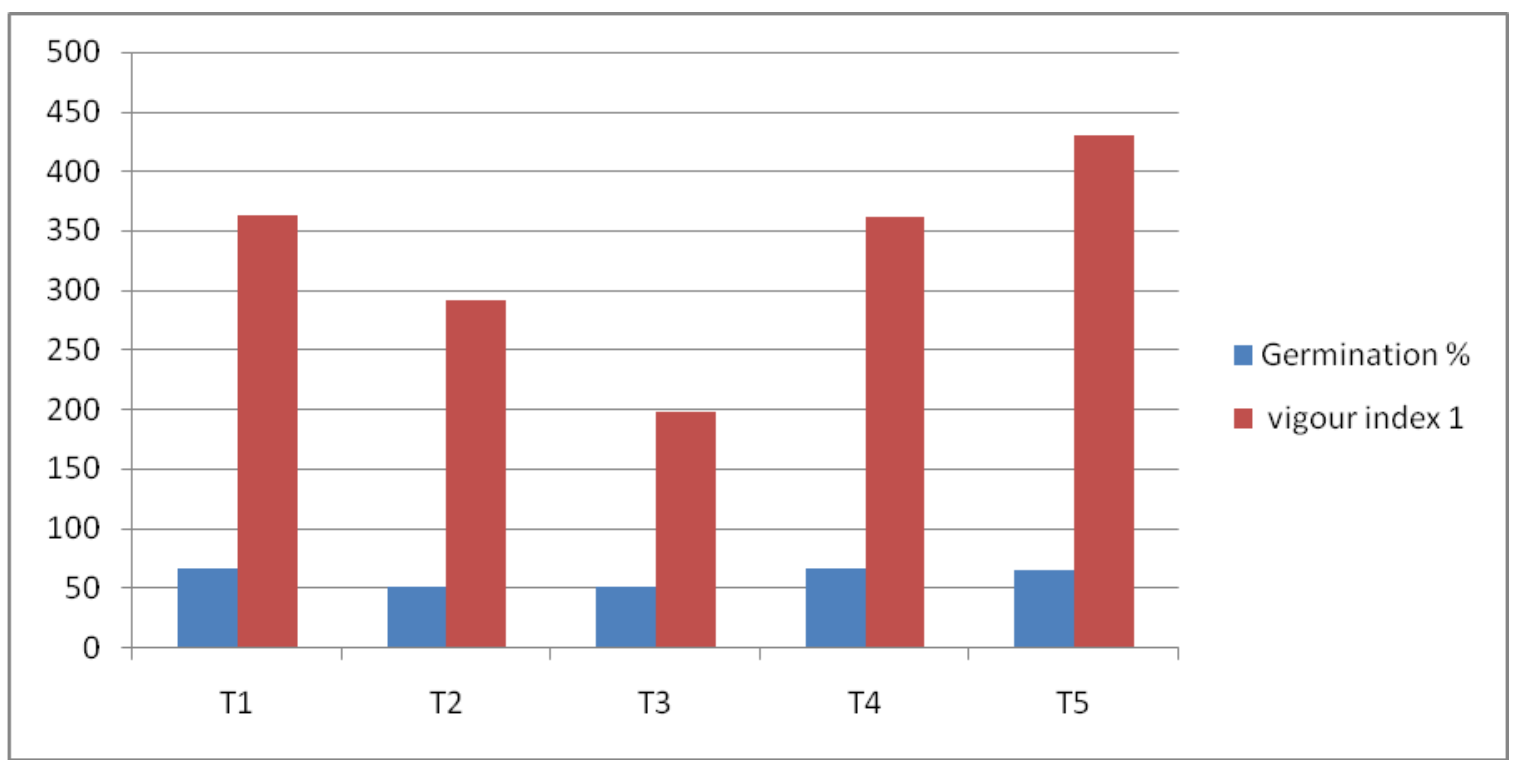

\section{Seedling length}

Highest seedling length was recorded in T5 (6.72) followed by $\mathrm{T} 2$ (5.53) and Lowest seedling length was recorded in T3 (3.88) (Fig. 2).

\section{Seedling vigour index 1}

Highest seedling vigour index 1 was recorded in T5 (430.08) followed by T1 (362.32) and Lowest was observed in T3 (197.24) (Fig. 3).

From the above research it can be concluded that among bio agents Bacillus-218, and Pseudomonas Y-19., FP-37., FP-11., S-90., three bio agents namely Bacillus-218, Pseudomonas FP-37 and S-90 show better result among all five bio control agents and enhance growth and other parameters such as 
Root Length, Shoot Length, Seedling vigour, Germination Percent, Speed of germination etc. Hence, these three bio agents with their strains i.e., Bacillus-218, Pseudomonas FP-37 and $\mathrm{S}-90$ can be further used to increase yield and get high productivity.

\section{Acknowledgement}

This research work wouldn't have been a success without the supervision and guidance of my advisor Dr. Deepti Prabha, and my colleague Mohammad Salman also the co author of the paper. We thank our all other colleagues who provided insight and expertise that greatly assisted the research work.

\section{References}

Abbass, Z and Okon, Y., 2000, Plant growth promotion by Azotobacter paspali in the rhizosphere. Soil. Biol. Biochem., 25: 1075-1083.

Burelle, K. N., Vavrina, C. N., Rosskopf, E. N., Shelby, r. A. 2002, Field evaluation of plant growth-promoting Rhizobacteria amended transplant mixes and soil solarization for tomato and pepper production in Florida. Plant and Soil. 238: 257-266

Burd. G.I., Dixon D.G. and Glick, B.R. 2000, Plant growth promoting rhizobacteria that decrease heavy metal toxicity in plants. Can.J.Microbiol., 33: 237-245.

Cook, R.J. and Baker, K.F., 1983, The Nature and Practice of Biological Control of Plant Pathogens. American Phytopathol. Society. St. Paul. Minnosota, pp. 539.

Chandanie,W.A., Kubota, M. and Hyakumachi， M., 2009,Interactions between the arbuscular mycorrhizal fungus Glomusmosseae and plant growth-promoting fungi and their significance for enhancing plant growth and suppressing damping-off of cucumber (Cucumis sativus L.).
Appl.Soil. Ecol., 41: 336-341.

Dar, R., Gupta, A. K., Chopra, S., Samnotra, R. K., 2010, effect of integrated nutrient management on Seed yield of okra (Abelmoschus esculentus (L). Moench). J. of Research, 9: 70-78.

Dursun, A., Ekinci, M. and Donmez, M. F., 2010, Effect of foliar application of plant growth promoting rhizobacterum on chemical contents and yield of cucumber (Cucumis sativus L.). Pak. J. Bot.425: 3349-3356.

Datta, M, Palit, R, Gupta, C.S.Manas, Pandit, $\mathrm{K}$ and Banerjee, S., 2011, Plant growth promoting rhizobacteria enhance growthand yield of chili. (Capsicum annuum L.) under field conditions. Australian J. of crop science. 5: 531536.

Gharib, F. A., Moussa, L. A., Massoud, O. N., 2008, Effect of Compost and biofertilizers on growth, yield and essential oil of sweet marjoram (Majorana hortensis) Plant. J. Agri. Biol., 10: 3817.

Gabriele Berg., 2009, Plant-microbe interactions promoting plant growth and health: perspectives for controlled use of microorganisms in agriculture. Appl Microbiol Biotechnol. 84: 11- 18

Gajbhiye, P., Sharma, R. R., Tewari, R. N., Sureja, A., K., 2010, Effect of inorganic and bio-fertilizers on fruit quality of tomato.

Glick, B. R. and Patten, C. L., Holguin, G. and Penrose, D. M., 1999, Biochemical and genetic mechanisms used by plant growth promoting bacteria. Imperial College Press, London Franken Berger W.T., pp. 125-140.

Hameeda, B., Srijana, M., Rupela, O. P. Reddy, G., 2007, Effect of bacteria isolated from composts and macro fauna on sorghum growth and mycorrhizal colonization. World $J$ Microbiol Biotechnol, 23: 883-887. 
Hayat, R., Ali, S., Amara, U., Khalid, R., Ahmed, I., 2010, Soil beneficial bacteria and their role in plant growth promotion. Ann Microbiol., 60: 579598.

Hemashenpagam, N., Selvaraj, T., 2011, Effect of arbuscular mycorrhizal (AM) fungus and plant growth promoting rhizomicroorganisms (PGPR's) on medicinal plant Solanum viarum seedlings. J. Environ. Biol., 32: 579583.

Kloepper, J. W., Leong, J., Teintze, M. and Schroth, M. N., 1980, Pseudomonas siderophores: A mechanism explaining disease suppressive soils. Curr. Microbiol., 4: 317-320.

Manikandan, R., SARAVANAKUMAR D., Rajendran, L., Raguchander, T., Samiyappan, R., 2010, Standardization of liquid formulation of Pseudomonas fluorescens Pf1 for its efficacy against Fusarium wilt of tomato. Biol. Control., 54: 83-89.

MANOJ, 2011, Yield and quality of potato (solanum Tuberosum) tubers as influenced by nutrient sources under rain fed condition of Meghalaya. Indian
J. of Agron, 56: 3

Mashooda Begum, Ravisankar Rai, V. and Lokesh, S., 2003, Effect of plant growth promoting rhizobacteria on seed borne fungal pathogens in okra. Indian Phytopath. 56(2): 156-158.

Nihorimbere, V., Ongenal, M., Cawoy1, H., Brostaux, Y., Kakana, P., Jourdan, E. and Thonart, P., 2010, Beneficial effects of Bacillus subtilis on field grown tomato in Burundi: Reduction of local Fusarium disease and growth promotion. African J. Microbiol. Res., 4 (11): 1135-1142

Poonguzhali, S., Madhiyan, M., Tongmin SA., 2006, Cultivationdependent characterization of rhizobacterial communities from field grown Chinese cabbage Brassica campestris ssp pekinensis and screening of traits for potential plant growth promotion. Plant Soil. 286: 167-180.

Sarathambal, C., Thangaraju, M., Kanimoli, S and Poorniammal, R., 2011, Evaluating the performance of liquid inoculants in Tomato. J. Soil.Biol. Ecol., 3: 9-16.

\section{How to cite this article:}

Sony Grace, Mohammad Salman and Deepti Prabha. 2019. Effect of Distinct Biocontrol Agents on Okra (Abelmoschus esculentus Monech) for the Selection of Putative Strain. Int.J.Curr.Microbiol.App.Sci. 8(02): 1112-1118. doi: https://doi.org/10.20546/ijcmas.2019.802.130 